Journal of the Faculty of Arts and Social Sciences

International University of Sarajevo

ISSN 1840-3719 / No. 4

Spring 2010

\title{
Privatization, Competition and Beyond
}

\author{
Mete GÜNDOĞAN \\ International University of Sarajevo
}

\section{Introduction}

Privatization in general can be seen as transferring or selling State Owned Enterprises (SOE) or assets to individuals or private firms. Ever since Britain began its large-scale privatization program in the early 1980s, many countries have experienced privatization on a massive scale but in different ways. Both developing and developed countries are putting up entire sectors for sale; they are selling even the enterprises, once considered vitally and indisputably important for nation, such as railways, national airlines, telecommunications, electricity production and distribution, and tap waters etc.

Privatization not only results only in the transfer of state assets to the private enterprises, but it also abolished the state monopoly, relaxing the restrictions on private-sector activities and allowing the entry of more private firms into the market. Reducing the economic role of the government through privatization is expected to lead to an improvement in the economy's potential growth. The current global enthusiasm for privatization suggests that reduction in the economic role of the government leads to economic efficiency and growth. Indeed, potential gains, as increases in efficiency, living standards and long run growth, are substantial in many countries (Schipke, A., 2001). Most studies show that countries that protect private property rights and rely on the private sector to produce goods and services have a better track record in terms of their growth performance than those that rely heavily on the public sector.

Sometimes it is said that policy makers have embarked on the sale of assets because of a change in their behaviour and have learnt much as a result of their past mistakes. In these cases, privatization failures may be attributed to shortcomings in the design and implementation of the privatization programs. Better advice could remedy these shortcomings in the case of ongoing of future divestitures. 
In industrialized countries with developed capital market, cash strapped governments facing with hard budget constraints resort to the sale of assets as a means of financing. Fiscal issues seem to be a key determinant of privatization. Financing government expenditures through the sale of assets encounters the least political resistance. Governments that maintain a given level of expenditure but reduce the publicly visible deficit through privatization may even be politically rewarded.

One of the other key determinants of privatization is related to balance of payments, crises and monetary policy. It can serve as an additional instrument for dealing with temporary surges in capital inflows.

However, counter processes can also be existed in the failure. Level of overstaffing in public enterprises suggests that profit-driven private investors who are free to reduce the labour force are likely to do so. The lack of wage flexibility and rigidities and imperfections of the labour market results in temporary, if not permanently, higher unemployment rates. If divestiture is not associated with tangible improvements in the structure of the economy as well as in the living conditions of the population, there is always a risk of government intervention and renationalization of the privatized industries by the disillusioned public.

\section{TRANSFORMATION THROUGH PRIVATIZATION}

According to Nestor and Mahboobi (2000), transformation through privatization can be studied from four such different point as political/philosophical, institutional/corporate governance structures, economic/industrial organization, and financial. All of them are important to understand the fundamental change that is currently occurring on a global scale in the area of utilities.

As to the four points above, first, governments seemed to have recognized politically what economists have long preached. Consumer welfare depends on efficiency with competing producers in factors and product markets and on higher productive efficiency in the use of inputs by individual firms through better incentives and finance mechanisms.

Secondly, privatization is also a response to the institutional failings of public governance. Transparency in arms-length relations has become much cheaper due to progress in information technology. This implies that the arms-length regulation is now less costly than the outright ownership. Corporate governance of widely-held private companies is also becoming more effective. Information 
asymmetries between shareholders and companies are becoming less pronounced, so that the corporate control can be more efficiently exercised through the markets.

Better corporate governance improves productive efficiency in individual firms by allowing for a better utilization of resources and more transparent allocation of financial resources. The biggest incentive for improving efficiency is, of course, coming from competitors. Technological innovation, deregulation and openness to foreign investment have been driving forces in introducing competition in utilities.

In the 1950s and 1960s, lack of financial resources in the private sector made utilities and infrastructures come under the government's purview. Financial markets were fragmented into closed national areas with low liquidity and insufficient savings. Similarly, the alternative of printing money proved to be catastrophic as the OECD area went through its worst inflation spell twenty years ago. Enterprises found themselves contained by public ownership (Moore, J. 1986).

But financial markets have changed enormously during the last three decades. Financial market liberalization and globalization trends have intensified since the beginning of the 1980s. Floating exchange rates since the early 1970s have rendered large budget deficits to finance public investment unsustainable. The growing demand for new and better infrastructure services in a tight-budgetary environment paved the way for greater private sector involvement in funding and providing such services, as a means of reducing governments' budgetary exposure.

\section{TURKISH EXPERIENCE}

Turkish privatization has proceeded in a slow and incremental manner; it began after 1984 and slowed in the 1990s but boosted in the 2000s. Consequences of the last phase have not been clear yet (Cizre, U. and Yeldan, E. 2005). It would not result in any change as for the aggregate output in a permanent way, as discussed by Bacchiocchi, E. and Florio, M. (2008) for the UK.

Turkey launched its comprehensive economic liberalization program under the name of 'structural adjustment reform' in January 1980. The World Bank and IMF had a crucial influence on the pattern of the reform program. Privatizing of public assets, creating a "flexible" labour market, replacing producer price subsidies in 
agriculture with direct income transfer program were the main issues of the structural adjustment (Onis, Z. 1991).

Privatization of SOEs emerged as an official state ideology after this liberalization program. The main ideological pillar of the initial attempts was announced as a matter of improving efficiency in production and reducing "excessive" employment and waste in the state enterprise system.

Privatization attempts have started in the beginning of 1984 by the law numbered 2983 that defines the transfer of shares, bonds, profits and management rights to the private entities. In a decade, nearly ten legal amendments and procedures have been made until the year 1994.

In 1994, the principles, procedures, authorized agencies and other issues regarding privatization are all set out in the Privatization Law numbered 4046. By this Law, an adequate framework, funds and appropriate mechanisms to speed up the privatization and restructuring processes have all been provided. The scope of assets to be privatized has also been expanded. Two structural institutions, namely the Privatization Higher Council (PHC) and the Privatization Administration (PA), have been established to facilitate and enhance decision making processes.

The PHC, headed by the Prime Minister and consists of four related ministers, is the ultimate decision making body. It nominates SOEs to be privatized together with the procedures and then gives final approval of the selling or transferring. The PA, on the other hand, is the executive body for the privatization processes. It is a legal public entity with an exclusive budget and accountable directly to the Prime Minister.

The PA (OIB, 2010) has set the privatization policy not only to minimize state involvement in economic activities and relieve the financial burden of SOEs on the national budget but also to contemplate the development of capital markets and re-channel resources towards new investments (Onis, Z. 1991). But it is also aware of the difficulty in having such an economy without a strong and healthy capital market. In order to obtain these achievements, on one hand, foreign investors are encouraged to invest in the Turkish capital market; on the other hand, divesting SOEs is resulting in reducing budget deficit. This is also considered a positive contribution to capital market. 


\section{PRIVATIZATION METHODS}

Companies are privatized through the use of one or more of the methods as follows: transfer of the ownership of companies in full or partial, transfer of shares of these companies through domestic or international public offerings, block sales to real and/or legal entities, block sales including deferred public offerings, sales to employees, sales on the stock exchanges by standard or special orders, sales to investment funds and/or securities investment partnerships by taking into consideration the prevailing conditions of the companies.

Leasing, granting operational or management rights, establishing property rights other than ownership are also valid methods of privatization. In coordination with the PA, such SOEs as Turkish Telecom, mobile licenses and state banks were privatized by different governmental agencies.

\section{PRIVATIZATION IMPLEMENTATIONS BETWEEN 1984-2009}

Privatization implementations have started in 1984 with the transfer of incomplete plants of the SOE's to the private sector for completion. In this way, 6 public plants were sold to different investors, and 9 plants were transferred to municipalities or to state enterprises on the book value.

Since 1985, state shares in 270 companies, 103 establishment, 22 incomplete plants, 8 toll motorways, 2 Bosporus bridges, 1 service unit and 524 real estates and 6 ports have been taken into the privatization portfolio. After a while, some of the companies, and real estates were excluded from the portfolio for various reasons. Two of these were Turkish Teacher's Bank which merged with Halk Bank in May 1992 and Navigation Bank which merged with Emlak Bank in November 1992.

In 1986, privatization implementations have gained momentum and since then, 199 companies have been privatized, and no more government shares exist in 188 of them.

Figure below shows the privatization implementations in between 1985 and 2009 (OIB, 2010). 


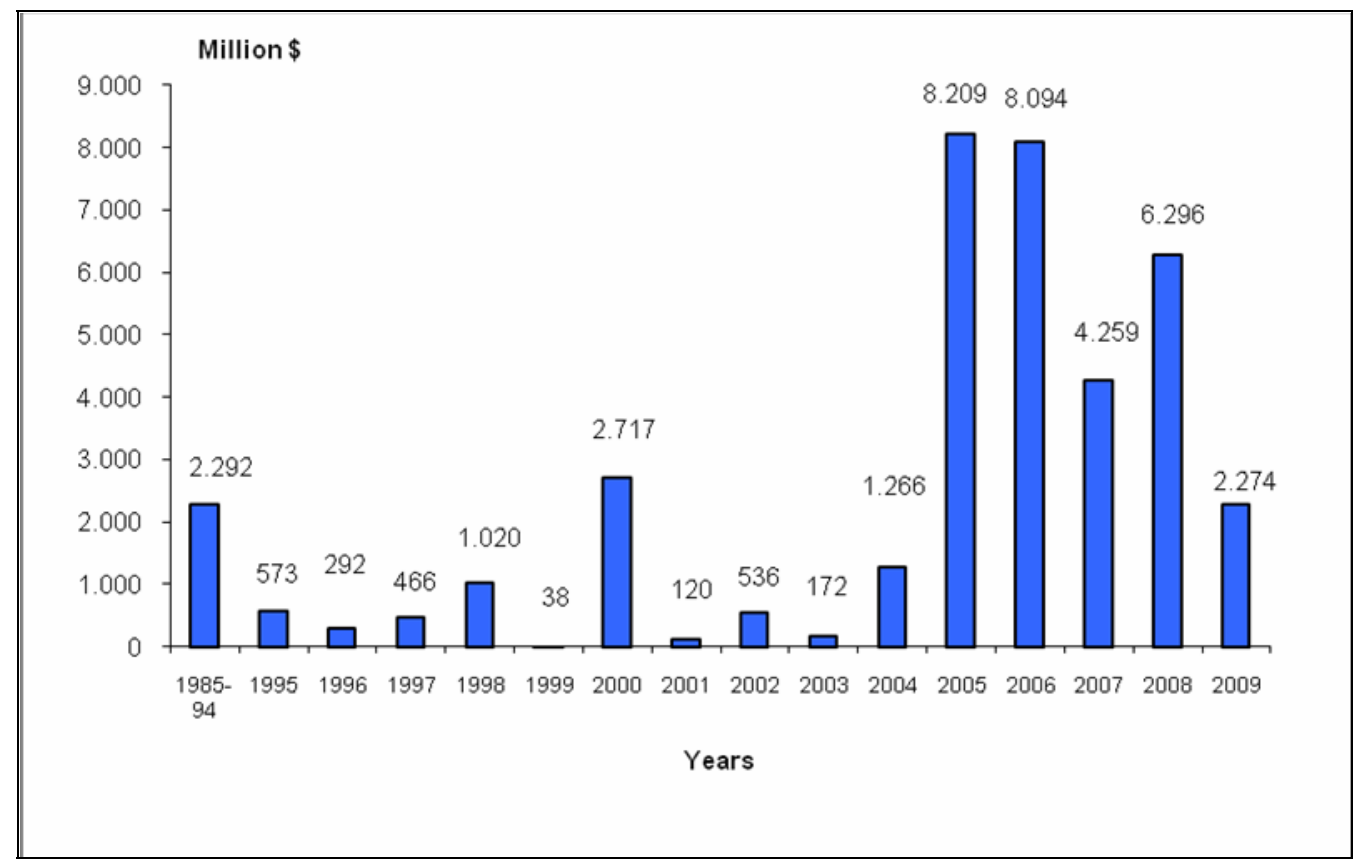

Since 1985 until today, the total proceed from the privatization implementations is recorded as USD 38.6 billion (OIB, 2010). The total revenue generated from entities within the privatization program between 1985-December 2004, together with USD 2.3 billion dividend income and USD 3.4 billion other income, has amounted to USD 14.3 billion. In the same period, total privatization expenses were USD 13.9 billion.

The largest item in privatization expenditures (with about 98\%) is the transfer to the Treasury and financing of the companies in the privatization portfolio in the form of capital increases and loans. Great amount of these transfers was then stopped.

\section{PRIVATIZATION GROSS REVENUES}

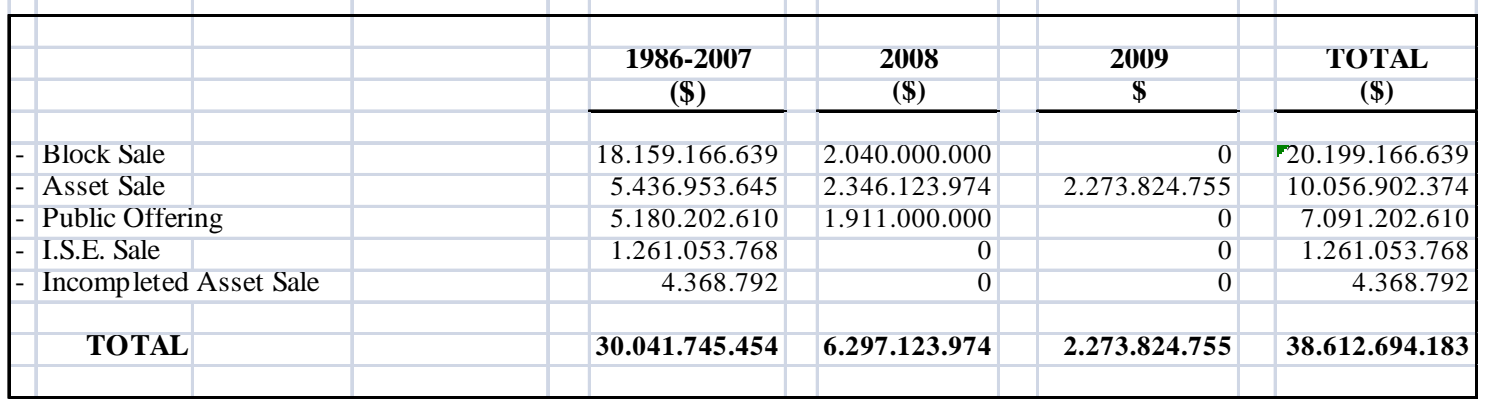

ISE: Istanbul Stock Exchange 
As results of privatization, the state economy no longer accounts for the majority of economic output. The state has also gradually lost its monopoly of resources, control and allocation. Considering the privatization implementations for the last 15 years, one would observe that:

- State completely withdrew from cement, animal feed production, milkdairy products, forest products, civil handling and catering services and petroleum distribution sectors.

- More than $50 \%$ of the state shares were privatized in tourism, iron and steel, textile, sea freight and meat processing sectors.

- State has withdrawn from most of the ports and petroleum refinery sector.

- Privatization of public banks has commenced with Sümerbank and continued with Etibank, Denizbank and Anadolu Bank. The international and domestic offering of the $12.3 \%$ state shares in İş Bank in May 1998, has been the largest public offering in Turkey until that time and recorded as one of the largest privatization proceeds among the emerging European markets.

- Public shares in Netaş and Tofaş were issued to foreign investors through international public offering for the first time, which served as a driving force of the integration of Istanbul Stock Exchange's (ISE) with foreign capital markets.

- Public shares in many companies were issued to the public, particularly in the beginning of this decade and this enhanced the institutionalization of ISE (OIB, 2010);

Currently, on the privatization portfolio, there are more than 15 companies including 52 run-on river hydro plants, sugar factories, tobacco products, electricity distribution, petrochemicals, telecommunication, banking, etc. Moreover, the PHC has recently put motorways and bridges and many state's railways' ports in the privatization portfolio.

\section{PRIVATIZATION AND COMPETITION}

Privatization and competition should be complementary to each other although it may take several years to build up a market-based institutional framework (Sondhof, H. 1999). Privatization can and should occur as a consequence of 
competition (Liu, G.S. and Garino, G. 2001). Privatization should be at the heart of efforts to create a competitive market (Matutes, J.S. 2000). In other words, privatization should result in strengthening competition and the competition should encourage privatization. Access to international capital markets has created several global, competitive companies out of hitherto inefficient state monopolies.

Competition and privatization are sometimes uneasy policy bedfellows. Incumbent firms may argue successfully that the purpose of privatization is to strengthen them, through a vastly increased possibility to tap international capital markets, so that they may become global players. But they need to maintain their dominant position at home, by regulatory or other de facto obstacles. This would create added gains for shareholders and thereby contribute to the development of the capital markets but a monopoly would still be the "natural" outcome of the market.

Policy makers have to weigh these "company" arguments against the longer term goal of enhancing competition and maximizing consumer welfare. Evidence suggests that in the initial stages of privatization, they were far too sympathetic towards companies, preserving competitors rather than competition.

After a decade of Turkish privatization implementations, a Competition Board, consisting of 11 members, was assigned on February 27, 1997 and the Competition Authority (CA) on November 5, 1997 as per Article 20 of the Act Numbered 4054.

Since 1997, the CA has issued a lot of procedures and guides for the applicability of the Act in competition field, most of which can be found on its web site (RK, 2010).

The main goal of the Competition Act is the prohibition of cartels and other restrictions on competition, prevention of abuse of dominant position by a firm which has dominance in a certain market and prevention of the creation of new monopolies by monitoring some merger and acquisition transactions. In order to achieve this goal, the CA:

- penalizes undertakings which distort or prevent competition in the market, through examination and investigation processes subject to detailed regulation,

- grants exemption to and prepares secondary regulations for agreements which are in conflict with competition rules but are beneficial for the economy and the consumers, 
- prevents monopolization within the market by examining mergers, acquisitions and joint-ventures over a certain threshold,

- in the privatization stage, examines the transfer of public undertakings to the private sector, and through privatization, reduces the effects of the state on the economy while preventing monopolization in the areas the public sector exits,

- ensures the dominance of competitive conditions within the markets by sending opinions on various acts and regulations which would negatively affect or restrict competition in the markets to government institutions and organizations concerned (The Competition Authority, 2008).

\section{CONCLUSIONS}

Privatization policies have multiple, and often inter-related and conflicting political, economic and financial objectives (Guislain, P. 1997). They must be evaluated according to political, social and economical structures and conditions of the country concerned.

Changing the corporate governance environment of SOEs generally results in improving their productive efficiency and performance by introducing incentives based on private ownership rather than bureaucratic oversight. Better incentives structure and corporate governance are important because they lead to better firm performance (Brown, D., Earle, J.S. and Telegdy, A. 2006). People become less dependent upon the state as the state no longer monopolizes most economic resources.

Privatized enterprises are freed from public sector constraints on investment. They can tap the unlimited supply of the capital markets without any impact on the state budget. Hence, providing better access to finance for enterprises generate higher levels of investment

Public sector borrowing requirements and public debts were two economic indicators deteriorating the state budget because of the humble SOEs. Privatizing them improves alike macroeconomic indicators and medium term budgetary revenues. Besides, it is deepening the equity market and the creation of a wide share owning class and is boosting the role of equity markets as a means of channelling savings in the economy. Another consequence of privatization is the structural change of the state's fiscal extraction. The percentage of government revenue with respect to GDP has been shrinking due to the reforms. But the government, instead, has strengthened the mechanisms for tax collection from 
the private sector. Redistribution of wealth through an efficient and honest taxation is required now than ever before. (Ahrend, R. and Winograd, C. 2006). If privatization is seen solely as a means to reduce budgetary deficits and not as a piece of the bigger puzzle of structural reforms, permanent political opposition against privatization would emerge, and privatization attempts may be blocked or under threat of reversal (Staikouras, P. 2004).

In Turkish case, improving public finances has become the most obvious privatization objective. Despite the difficult market conditions, approximately 30 billion dollars (29.132BUSD) has been raised in privatization proceeds. The importance of these revenues for the government budget has been engaged in meeting debt and deficit targets in the run up to the EU Accession (Yesilada, B.A. 2002).

At the same time, the CA is trying to establish a free and sound competitive environment for the market for goods and services. But endeavours are not clear for the production factors and capital markets. This would be because of its inexperienced or immature character. By the time elapsed, regulations and interests can encompass these areas as well.

There seemed no direct relationship with the privatizations endeavours apart from examining the transfer of public undertakings to the private sector to prevent monopolization in the areas the public sector exited.

Introducing competition in a relatively closed market results in lowering prices and increasing the quality of infrastructure products and services. In the context of utilities, competition is often a primary and a "must-be" objective. The reason is two-fold. Contrary to other sectors, utility provision is often monopolistic for a variety of reasons. Secondly, utilities provide services that are important for the well being of the economy, for consumer welfare and thus a highly visible priority of any public policy. Privatization offers an opportunity to break up monopolies and to improve efficiency and consumer welfare.

The preliminary cost is a loss of the security previously granted by an allencompassing state through SOEs. Therefore, the primary consequence of unemployment and privatization is social unrest. A variety of actions against bankruptcy, salary arrears, and the restructuring or sale of SOEs are reported. Actions include visits to government offices, demonstrations, marches in and blocking of streets, letters of complaint to officials, sit-ins in front of government buildings, petitions and protest rallies. Such actions are occasionally more violent including sabotaging factory equipment, attacking offices, committing arson against state property, and detaining, attacking managers and bosses. 
Since privatization is still under way in Turkey, and many variables and uncertainties are evolved, any assessment of its possible long-term effects can only be tentative. In the short run, pressures coming from public sector borrowing requirements and public debts are released. It seems to be resulted in relatively better debt management. But, without having a proper competitive market, without having a sound social security system and without having a profound capital market, Turkey seems to be a bare-foot runner in its privatization venture.

\section{REFERENCES}

1. Ahrend, R. And Winograd, C. (2006), "The Political Economy Of Mass Privatization And Imperfect Taxation: Winners And Loosers", Public Choice (Springer 2006) 126: 201-224.

2. Bacchiocchi, E. and Florio, M. (2008)," Privatization And Aggregate Output: Testing For Macroeconomic Transmission Channels", Empirica, 35: 525545, Springer Science and Business Media, LLC.

3. Brown, D., Earle, J.S. and Telegdy, A. (2006), "The Productivity Effects Of Privatization: Longitudinal Estimates From Hungary, Romania, Russia And Ukraine", Journal of Political Economy, vol. 114, No. 1, The Univesity of Chicago.

4. Cizre, U. and Yeldan, E. (2005), "The Turkish Encounter With NeoLiberalism: Economics And Politics In The 2000/2001 Crises", Review of International Political Economy, Vol. 12, No. 3 (Aug., 2005), pp. 387-408.

5. Guislain, Pierre. (1997), "The Privatization Challenge", The World Bank.

6. Liu, G.S. and Garino, G. (2001), "Privatization Or Competition? A Lesson Learnt From The Chinese Enterprise Reform", Economics of Planning 34: 37-51, Kluwer Academic Publishers.

7. Matutes, J.S. (2000), "Privatization and Local Governments in Mainland China: A Critical Assessment", Intereconomics, May/June 2000.

8. Moore, Jim. (1986), "Why Privatize" in John Kay, Colin Mayer and David Thompson "Privatization and Regulation - the U.K. Experience" Clarendon Press.

9. Nestor, S. and Mahboobi, L. (2000), "Privatization Of Public Utilities: The OECD Experience", Privatization, Competition And Regulation, OECD Publications, OECD, Paris, pp.13-49.

10.0IB. (2010), Özelleştirme İdaresi Başkanlığı, The Privatization Administration of The Turkish Republic Web Page; http://www.oib.gov.tr/index eng.htm

11.Onis, Z. (1991), "The Evolution Of Privatization In Turkey: The Institutional Context of Public-Enterprise Reform", Journal of Middle East Studies, Vol. 23, No. 2, pp. 163-176 Published by: Cambridge University Press. 
12.RK. (2010), Türkiye Rekabet Kurulu, The Turkish Competition Authority Web Page; http://www.rekabet.gov.tr/index.php?Lang=EN

13.Schipke, A., (2001), "Why Do Governments Divest?: The Macroeconomics of Privatization", Springer, Berlin.

14.Sondhof, H. (1999), "Privatization Policy In Russia”, Intereconomics, September/October 1999.

15.Staikouras, P. (2004), "Structural Reform Policy: Privatization And Beyond - The case of Greece", European Journal of Law and Economics, 17: 373398, 2004, Kluwer Academic Publishers.

16.The Competition Authority. (2008), 11 th Annual Report, 2008, Ankara.

17.Yesilada, B.A. (2002), “ Turkey's Candidacy For EU Membership”, Middle East Journal, Vol. 56, No. 1, (Winter, 2002), pp. 94-111. 